\title{
野生哺乳類、特にネズミ類の遺伝学
}

\author{
鈴木 仁 \\ 北海道大学大学院環境科学院
}

\section{Genetic studies with murids and other mammalian species}

\author{
Hitoshi SUZUKI
}

Laboratory of Ecology and Genetics, Graduate School of Environmental Science, Hokkaido University

\section{要旨}

日本列島には特筆すべき野生の哺乳類が多い。例え ば、琉球列島のトゲネズミはY 染色体の一部がX 染 色体に転座した X0 型で、性決定機構の解明に有益で ある。伊豆諸島を含め日本全国に生息するアカネズミ はロバートソニアン型変異や数十万年間の隔離のゲノ ムへの影響を検討できる逸材である。ニホンヤマネは 数百万年前に分岐が始まった複数の地域集団を持つ。 これらの野生哺乳類は第四紀の地球環境の変動や陸橋 形成などの日本列島の地史を知る上で有益情報をもた らすであろう。ハッカネズミやクマネズミの遺伝子を 解析すると、数回の移入の歴史が観察された。数千年 前から現在にかけての列島人類史解明への貢献が期待 されている。また、豊かな毛色変異があるテン類 (イ 夕チ科) は MC1R 遺伝子に高頻度のアミノ酸置換を伴 う変異が観察された。機能遺伝子の变化の究極的意 味を知る上でもこのような野生生物の研究は重要で ある。以上のように野生の哺乳類をみるだけでも、 日本列島は遺伝学的研究にとって資源の宝庫といえ るだろう。

\section{1. はじめに}

人類史は、チンパンジーとの分岐後の 500 万年間、 そしてアフリカを出た後の過去 5 万年間が重要であ る。すなわち、アフリカ大陸での分断とアフリカ出後 の分散である。分断や分散によりゲノムがどのように 変革され、系統分化が起こるのかを知ることは興味深 い。500万年間という長い時間の流れの中での変化や 系統が地表を移動することでゲノムの改変にどのよ うな影響がでるのかを知りたいと思ったとき、我々 は日本列島という地にあり、実は身近な野生の哺乳 類が頼りになるのではなかろうか。ここでは、この ような観点での日本産野生哺乳類の研究活用例を紹
介していきたい。1）哺乳類種の自然史、2）日本列島 の地史、3）日本人の起源、4）遺伝子・染色体の進化、 の 4 つの項目について焦点をあてる。

\section{2. 日本産哺乳類の起源}

まずは、日本列島の現生哺乳類相の歴史を考えたい。 現生の哺乳類につながる化石は古くても50-60万年前 のものしか存在しない。一方で、分類学者の一部は、 その形態の特異性から第三紀起源を唱えている。近年、 分子系統学的解析が日本を含むアジア域の哺乳類につ いて精力的に行われ、その結果、日本産種の類縁関係 や分岐年代が推定されるようになった。そこで、ヤマ ネ類 1 種、ネズミ類 11 種、イタチ科 2 種、ウサギ類 3 種を選び、これらの種と最も近縁と思われる大陸種を 想定し、その日本と大陸種間の遺伝的距離を求めた。 同種が大陸にも生息する場合は、大陸の最も近縁であ ると想定される集団と比較した。分岐年代の推定の際 には、古い関係の場合は核遺伝子の配列を用い、新し い関係についてはミトコンドリアDNAの配列を活用 した。所定の方法で分岐時間を推定し、結果を図 1 に まとめた。この図より、主だった日本の固有種は第三 紀後期の起源であり、数百万年の歴史を持っているこ とがわかる（Hosoda ら 2000; Tsuchiya ら 2000; 鈴木 2002、2003; Yamada ら 2002; Suzuki ら 2003; Shinohara ら 2003、2004; Sato ら 2004; Nunome ら未発表)。モグ ラ類についても列島は種数が豊富で7種ほどを産し、1 種 (コウベモグラ) を除き、すべて固有種である。分岐

連絡先：鈴木 仁、北海道大学 大学院環境科学院 生態遺伝 学講座 $\overline{\mathbf{T}} 060-0810$ 札幌市北区北 10 条西 5 丁目

(e-mail: htsuzuki@ees.hokudai.ac.jp) 


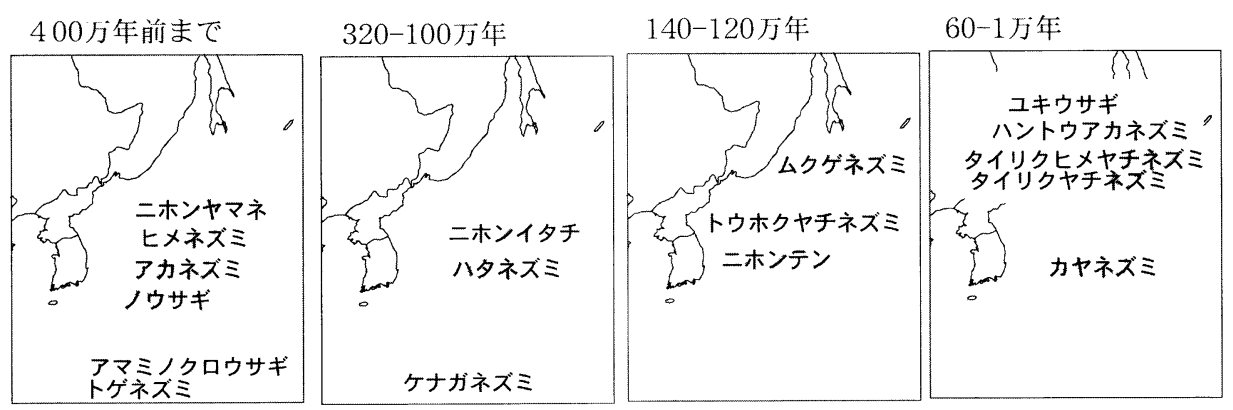

図1.日本産小型哺乳類と大陸近緣種との分岐年代の推定

核の遺伝子およびミトコンドリア cytb遺伝子の塩基配列の変異に基づき、日本産哺乳類種について大陸の近縁種 との分岐年代を推定した。琉球列島や本州域に第三紀起源の古い系統が息づいていることがわかる。推定した年 代の正確性は今後検討する必要がある。

年代の推定に必要な有効な化石資料が不足しているた め、詳細は不明であるが、遺伝的距離の大きさから推 察される限りではモグラ類固有種の起源は第三紀後期 であると思われる。以上のように、日本列島の哺乳類 相の歴史は相当古い。このことは、 500 万年間程度の進 化的時間の中での遺伝的変異を理解する上で格好の材 料が身近に存在しているということを意味している。

\section{3. 日本列島の地史にせまる}

哺乳類の歴史から地球の歴史を学ぶことも可能であ る。例えば琉球列島のアマミノクロウサギとトゲネズ ミは大陸の近縁種と比較するとおよそ8000-9000万年 前と推定され、琉球列島形成の歴史の理解に重要な知 見を提示している(図 1)。本州にも固有種が多く、第 三紀後期の大陸との地質学的状況を把握する際に、有 益な情報を与える。また、さらに細微な空間に目をや ると、アカネズミは伊豆諸島や南西諸島に唯一生息す る在来種で、各島嶼集団が独自のタイプを保持してい ることが明らかとなった(図 2)。この島嶼集団の遺伝 的固有性から、これらの島には数十万年前にアカネズ ミが自然分布したということはもはや疑う余地はなく なった (Suzuki ら 2004)。伊豆諸島は火山島で、本州 との接続はないとの説もあるが、なんらかの要因によ り、アカネズミが 20 万年前ころに渡ったのであろう。 $200 \mathrm{~m}$ 以上の深い海で隔てられてはいるが、ネズミが 渡れるだけの間隙が狭まったものと思われる。同じく 深い海で隔てられている南西諸島の口之島や西ノ島な どにおいても 10 万年ほど前に分岐したと思われる固 有のミトコンドリアのハプロタイプが観察され、自然 分布の証を提示している。一方、ヒメネズミも佐渡、 隠岐、薩南諸島に分布し、そのミトコンドリアDNA
のハプロタイプは本土のものと著しい類縁性を示し、 最終水期に集団の流入があったことを示唆している (Suzuki ら 2004)。すなわち、佐渡や屋久島は過去数 十万年間に複数回の本土との陸橋形成があったことが 理解できる。このように、土着のネズミ類の遺伝的解 析により、第四紀の水期サイクルをめぐる陸橋形成を 含めた環境変動の歴史を明らかにする上で有力情報が 得られるのである。また、ヤチネズミ類では第四紀の 環境変動と東西のヤチネズミの移動との関連が示唆さ れている。紀伊半島の隔離されたトウホクヤチネズミ は集団サイズが小さいと思われるにも関わらず、その 遺伝的多様性は高く、これは関東、東北集団との隔離、 融合が繰り返された結果であることが示唆されている (Iwasa と Suzuki 2002、2003)。このように、次々に明 らかにされるネズミ類等の小型哺乳類の遺伝的構造は これまでの常識からは予見できないことも多く驚きの 連続ではあるが、彼らの分布や生息が環境条件に密接 に関係することもあり、日本列島の歴史を理解する上 で有益な情報であることは間違いない。

\section{4. 日本人の歴史をネズミから学ぶ}

\section{1.八ツカネズミ}

人類が 5 万年ほど前にアフリカを出たのち、その後 どのような経緯で日本列島に辿り着いたのであろうか。 日本人の起源については諸説あるが、北方アジア系 (あるいは弥生系) とされる系統と南方アジア系 (ある いは縄文系) とされる系統が日本列島で会合している という見解には異論はないものと思われる。問題は、 北方に存在する南方アジア系の要素の移入の経路であ る。これには、1）琉球列島を介して南方より、あるい は2）サハリンを介して北方より、という二つの異なる 

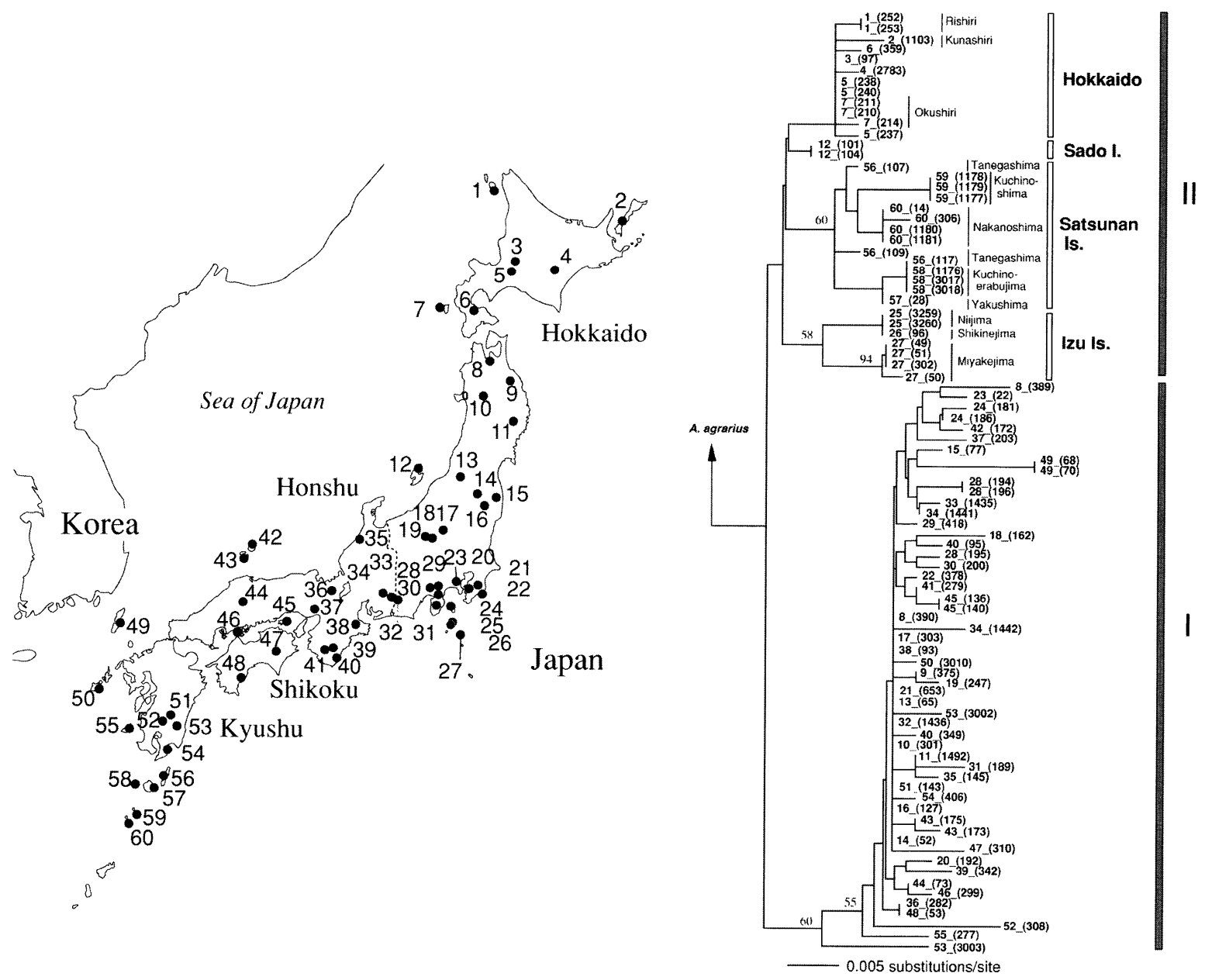

図 2.アカネズミから列島の歴史を推察

ミトコンドリア cytb 遺伝子の塩基配列の多型に基づき、近隣結合法により作成された系統樹 (Suzuki ら 2004)。 アカネズミのハプロタイプは二つのクラスターに分けられ、それぞれ、本州、四国、九州およびその近隣の島々 を含む本土集団 (グループI)、そして佐渡、北海道、伊豆諸島、薩南諸島を含む周辺離島集団 (グループII)には っきりと分化している。アカネズミには黒部川、天竜川を結ぶ線上に核型変異の境界線が存在するが、ミトコン ドリアDNAの多型解析は、この境界線を越えてハプロタイプの流動があることを示した。

見解がある。この問題を解く鍵の一つとして、ヒトと ともに渡来したとされるハッカネズミは注目を浴びて きた(森脇 1999)。世界中に生息するハツカネズミ（Mus musculus) は、ミトコンドリアDNAの解析により 4 亜 種グループに大きく分けられ、そのうち北東アジアに 主に分布するM. m. musculus 亜種グループを musculus （MUS）型、東南アジアを中心に分布する $M . m$. castaneus 亜種グループを castaneus (CAS) 型とした場合、 ミトコンドリアDNAの解析から、主要素は MUS 型で あるが、北海道、東北には CAS 型も混在することが明 らかになっている(図 3)。しかし同じ個体でSry を解析 すると、すべて MUS 型であった（Terashimaら 2005）。
さらに、核の遺伝子、IRBP (1152 bp) およびRAG1 (1002 bp) を系統地理学上のマーカーとして活用した ところ、日本産個体では IRBP、RAG1 ともに MUS 型 とともに低頻度でCAS 型が検出され、さらにIRBPで は「5 番目」の新しい配列がみつかり、また、RAG1の CAS 型においても種々の多型が観察されるなど、日本 列島のハツカネズミの遺伝的構造はかなり複雑である ことも分かってきた (Nakajimaら 未発表)。しかし、 ロシア極東産と北海道産のハッカネズミが同様のCAS 型の多型を共有することから、東南アジア系の北方由 来の可能性も示唆されている (Nakajimaら 未発表)。 この日本列島におけるハッカネズミの解析は日本人 


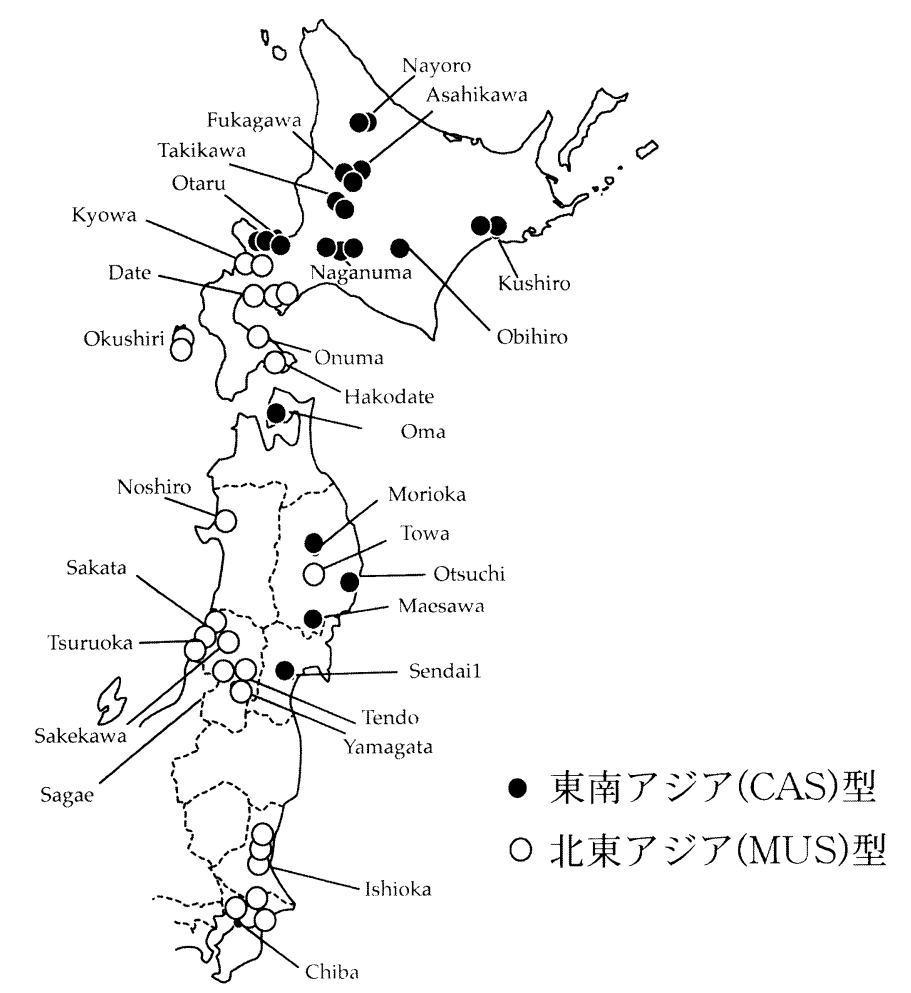

図3. ハツカネズミの地理的変異

ミトコンドリアDNAの列島内の多型（Terashima ら 2005)。北海道、東北に東南アジア型のハプロタイプが存在 する理由はなぜであろうか。

の起源を探る上でも重要であるが、遗伝的構造の理 解にむけた基本的立場を決定する点においても重要 な問題を提示している。つまり、1) 異なる系統が移 入した結果、遺伝的構造が構築されたと考えるか、あ るいは2）分布域全体のおける双方向のランダムな遺 伝子流動が長期間行われた結果と考えるかは大きな違 いがあるが、まさに日本列島のハツカネズミの問題は 解釈の方向性という系統地理学上の重大な問題点その ものの妥当性を吟味していく上で貴重な題材を提供し ていると考えている。

なお、今回の核遺伝子の解析から、核遺伝子の配列 がネズミ類に打いては少なくとも系統推定の有効なマ 一カーとなりうることが証明された。そもそも IRBP や RAG1 は哺乳類の目間関係を解像するために使用さ れてきたことを考えると、種内変異の解像に利用でき ることはこれ自体が驚きに值する。今回の核遺伝子領 域は、ミトコンドリアDNAの扔よそ 1 割程度の変異 量しか示さないが、遺伝子の系譜の構築には十分な量 の変異量を示す。また、今回のハッカネズミの配列中 には、組換えのシグナルは観察されず、へテロ接合を
持つ配列も節約的な考えに基づいて分離をすることが 可能であった (Nakajima ら 未発表)。今後、さらに多 くの系統地理学上の核遺伝子マーカーを開発、活用す ることで、ハツカネズミの問題の核心に迫れるものと 考えている。

\section{2. クマネズミ}

一方、同じく住家性ということで、アジアに深く根 づき、日本列島にも生息するクマネズミ(Rattus rattus) についてもふれておきたい。クマネズミには、形態や 核型から、オウシュウクマネズミ $(2 \mathrm{n}=38)$ とタネズミ $(2 \mathrm{n}=42)$ という二つのグループが存在すると一般には 考えられている。列島には後者が主流であるが、小樽 では前者が生息中である (図 4)。cytb 遺伝子の解析を 行ったところ、確かにオウシュウクマネズミ型であっ た。興味深いことに鹿児島は核型はアジア型、cytbは オウシュウ型であった。小笠原父島は cytbはアジア型 であったが、IRBPの配列からは二つの系統が混じっ ていることが明らかとなった (Chinen ら 未発表)。こ のような例をみると、クマネズミは近年急速に遺伝的 


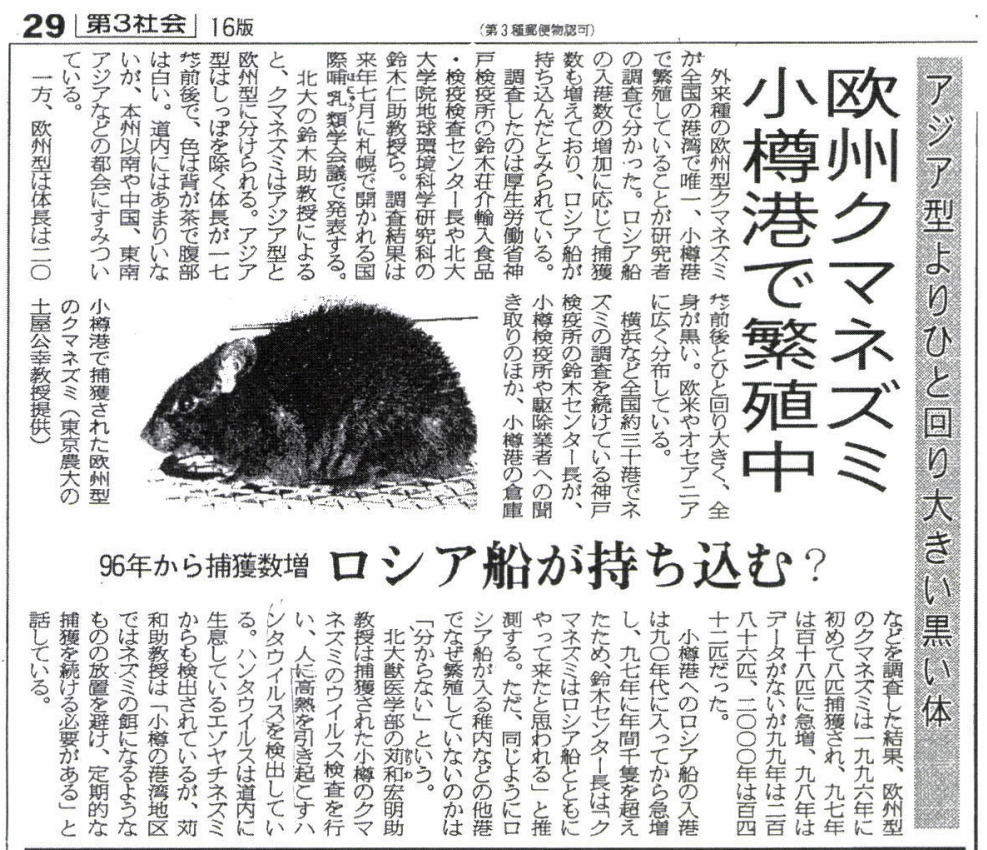

図 4. 小樽にオウシュウ型のクマネズミが出現 北海道新聞 $(2004$ 年 12 月 30 日) より。
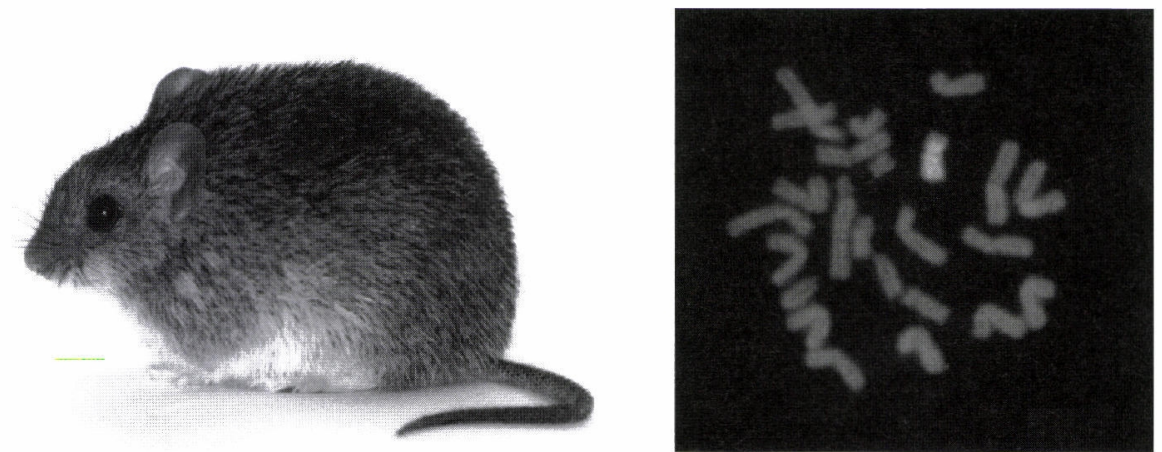

図 5. トゲネズミと奄美大島産由来細胞の染色体 マウスのX染色体プローブを用いてトゲネズミ雌個体 $(2 \mathrm{n}=25)$ の Zoo-FISH を行ったところ、X染色体は 1 本のみ特定された (Arakawa ら 2002)。生体写 真は土屋公幸氏撮影。

構造が変容している種であると思われる。遺伝学的な 手法で彼らの現代に扔ける移動履歴を追跡する必要が あるのではないだろうか。人獣共通感染症の関係もあ り、今後も目がはなせない。しかし、大陸のクマネズ ミの集団構造の解析は、その広域分布、歴史の古さか ら、かなり複雑で、全容解明にはまだ時間がかかりそ うな気配である。

\section{5. 実際の進化の中でのゲノムの改変作業を理解する}

5.1. Y 染色体の消失

数百万年の間のゲノムの変化は十分に目を見張るも
のがある。その際たる例をトゲネズミにみることがで きる。トゲネズミ(Tokudaia osimensis) は、南西諸島の 奄美大島、徳之島、拈よび沖縄本島に棲息する日本固 有の野生のネズミである。このネズミは３島それぞれ に拈いて異なった核型をもっており、奄美大島産は $2 \mathrm{n}=25$ 、徳之島産は $2 \mathrm{n}=45$ 、そして沖縄本島産は $2 n=44$ となっている。特に奄美大島産と徳之島産の個 体は染色体数が奇数で X0 型の核型をもち、雌雄差は ない。トゲネズミは国の天然記念物に指定されており、 近年棲息環境の悪化から急激に個体数が減少している ため、捕獲は困難な状況となっている。 
奄美大島産㧍よび徳之島産卜ゲネズミ雌雄個体それ ぞれのゲノム DNA と、北海道大学創成科学研 (旧理学 部附属動物染色体研究施設) に保存されている細胞を 用いてX 染色体の解析とヒト・マウスに扔ける Y 染色 体連鎖遺伝子のトゲネズミホモログの解析を行った (Arakawa ら 2002)。マウスのX染色体特異的ペインテ イングプローブを用いてトゲネズミの染色体にZooFISH を行った結果、奄美大島産個体抢上び徳之島産 個体ともにX染色体のみが特異的に染色された(図 5)。 二つの Y 染色体遺伝子、Tspy (testis-specific protein Y) 遺伝子と Zfy 遺伝子について FISH マッピングを行っ たところ、X 染色体の長腕末端部がマップされた (Arakawa ら 2002)。トゲネズミに扔いては、Y染色体 の一部が X染色体に転座していると考えられた。現 在、北海道大学創成研究機構において、トゲネズミの 性決定機構をめぐる謎の解明にむけた研究が行われて いる。

\section{2. ロバートソニアン型変異}

ヒト $(2 \mathrm{n}=46)$ は近縁なチンパンジー $(2 \mathrm{n}=48)$ やゴ リラ $(2 n=48)$ と比較し、ロバートソニアン型の核型変 異が生じて扔り、その種分化初期段階に扔ける核型変 異の影響が議論されている。アカネズミに扔いてまさ に同じ染色体数の同じロバートソニアン型変異を観察 することができ、まさに系統分化のまっただ中の中で 核型変異の役割を推察する上で格好の研究対象となっ ている。

図 2 にはミトコンドリアDNAの変異の解析結果が すでに示されている。これから、核型変異の境界線を 越えて、遺伝子は流動していることがわかる。核の遺 伝子の解析に扔いても同様の結果が得られている (Tomozawa ら 未発表)。これより、核型の変異は遺伝 子流動に大きな影響を及ぼしてはいないことが理解で きる。さて、ここで興味ある問題点が浮上する。つま り、遺伝子や個体は境界線を越えて自由に流動してい るにも関わらず、ロバートソニアン型変異がなぜその 境界線に留まっていられるかが疑問となる。Saitoh と Obara (1988) はこの問題に解答例を示している。雑種 型 $(2 n=47)$ の減数分裂時には $2 n=46 、 2 n=48$ のホモ 型と比較し、有意に異常が観察されることを示し、 heterozygote disadvantageにより、post-meiotic 隔離が 引き起こされていることを推察している。すなわち、 境界線を越えて移動する個体数は極端に限られている ので、問題の染色体は常にへテロで保たれていること が予想される。核型がへテロとなった個体は、子供を
多く産めない。よって、境界線を越えたロバートソニ アン型変異の当該染色体は、いずれ集団から消えてい くのであろう。一方、他の染色体上の遺伝子やミトコ ンドリア DNA は、 $2 \mathrm{n}=47$ からの木モ型の子孫を介し て遺伝子の交流が起きているものと考えられる。問題 の染色体上の遺伝子において遺伝子流動がどの程度妨 げられているかといった問題等、多くの興味深い問題 が残されている。

\section{3. 核遺伝子の塩基多様性}

ヒトは核の遺伝子をチンパンジーと比較すると数\% の塩基の違いが認められ、ヒトの集団で比較するとお よそ $0.1 \%$ 塩基の多様度があることが報告されてい る。そして、この集団中の多様度は進化過程に扔ける 1 万人という有効集団サイズに起因するとされている。 この遺伝的多様性のレベルが本当にどのような要因に より規定されてくるのかは興味あるところである。上 述のように系統解析の過程の中で核の遺伝子の配列を 解析していくと、その多様度は種によって大きく異な っていることを実感できる。例えば、アカネズミ類を 例にとろう。アカネズミ類 (Apodemus 属) は日本には 3 種生息し、うちアカネズミとヒメネズミは日本固有 種で、ハントゥアカネズミは北海道のみに生息する。 これら 3 種で 2 つ遺伝子で塩基多様度の比較を試み たところ、大きな違いがあることが判明した。広い分 布域を持ち、大陸産個体もあわせて解析したハントウ アカネズミの塩基多様度は IRBP (1152 bp) 領域におい て、打よそ $0.1 \%$ 、日本固有種のアカネズミは拉よそ $0.5 \%$ 、ヒメネズミは拉よそ1\%であった。分布域の 広さには関係はなさそうである。RAG1 (1002 bp)の同 様の解析においても同様の傾向が認められた。それぞ れの種が持つ、ある特定の遺伝的多様性のレベルが、 どのような歴史的経緯で決定されたのか論じる上で、 日本産および大陸産の種を比較検討することは有益で あろう。さらに、集団レベルでの遺伝的多様性のレベ ルの違いを比較検討することも重要である。前述した ようにアカネズミの島集団は自然分布であり、数十万 年間隔離された集団における遺伝的改変の状況を把握 するには絶好の材料である。

\section{4. 毛色に関する遺伝子の進化}

最後に、遺伝子が進化的時間の中で、まさにどのよ うな力によって改変を行っているのかを知ることは時 代の流れでもあり、是非とも押し進めていきたいとこ ろである。身近な野生の哺乳類を対象にそのようなこ 
とを学ぶことは可能である。ここでは、イタチ科動物 の毛色の遺伝子の改変について紹介したい。イタチ科 はミンクやクロテンでみられるように、種間、種内の 毛色の変異性が豊かであることで知られる。哺乳類の 毛色に関する遺伝子は多々あるが、中でも MC1R は有 名である。イ夕チ属 8 種、テン属 8 種においてこの遺 伝子の前半領域を比較した解析の結果、テン属には欠 失があることが判明した（Hosoda ら 2005）。面白いの はこの欠失があるからといって種間の毛色の違いとの 対応がつかないことである。しかし、一方で、クロテ ンに抒いては、北海道内で塩基の多型があり、毛色の 多型と関連性が示唆された。また、非同義置換/同義 置換 $(\mathrm{dN} / \mathrm{dS})$ 比をみてみると、テン属で 1.4、イ夕チ 属で1.0であった (Hosoda ら 2005)。すなわち、一般 の遺伝子領域に比較し、MC1R 遺伝子領域においては、 アミノ酸置換を伴う変異が、進化的過程の中で高頻度 に出現しているのである。一方、同じ領域をネズミ類 で比較すると 0.4 程度とかなり低い。それでもこの值 はIRBP、RAG1 といった遺伝子の值より大きい。イ 夕千科動物の場合は天敵対策というよりも性選択のほ うに重きがあり、ネズミ類の場合にはなるべく保守的 であるほうがよいという力が㗢いているのかもしれな い。毛色の遺伝子がどのような力を受けて進化するか は興味深い問題である。野生生物が示す様々な形質の 変異に着目することで、その形質の責任遺伝子群の進 化に扮ける変化の究極的意味合いを理解する手がかり を得ることができるものと考えている。

\section{6. まとめ}

東アジアの哺乳類相はアカネズミ属をはじめとし て、第三紀後期の過去 1000 万年間の進化的時間の中 で形成されてきた。また、種内の遺伝的多様性をみて みると、日本列島をはじめとして南北に長い地形の複 雑さと第四紀の地球環境の変動の中から構築されてき たことがうかがえる。素性が明らかにされつつある日 本産小型哺乳類を題材として、生物の多様性を理解す る上で有益な遺伝学的解析を画策することが可能とな っている。

\section{謝辞}

本研究は次の方々をはじめ、多くの方々の多大なる ご協力を得て行われました。ここに厚く謝意を表しま す(敬称略)。森脇和郎(理研バイオリソースセンター)、 米川博通 (東京都臨床科学研究所) 、土屋公幸 (東京農 業大学農学部畜産学科野生動物学研究室)、岩佐真宏
（日本大学生物資源科学部動物資源科学科野生動物学 研究室)、篠原明男 (宮崎大学フロンティア科学実験総 合センター)、佐藤淳 (福山大学生命工学部生物工学科 動物細胞工学研究室)、松田洋一 (北海道大学創成科学 研)、梅原千鶴子 (北海道大学創成科学研)、鈴木荘介 (神戸検疫所)、細田徹治 (耐久高校)。

\section{引用文献}

Arakawa Y, Nishida-Umehara C, Matsuda Y, Sutou S, Suzuki H. 2002. X chromosomal localization of mammalian Y-linked genes in two XO species of Ryukyu spiny rat. Cytogenetic and Genome Research, 99: 303-309.

Chinen AA, Suzuki H, Aplin KP, Tsuchiya K, Suzuki S. 2005. Preliminary genetic characterization of two lineages of black rats (Rattus rattus sensu lato) in Japan, with evidence for introgression at several localities. Genes and Genetic Systems, (in press).

Hosoda T, Sato JJ, Shimada T, Campbell KL, Suzuki H. 2005. Independent nonframeshift deletions in the MC1R gene are not associated with melanistic coat coloration in three mustelid lineages. Journal of Heredity, 96: 607-613.

Iwasa MA, Suzuki H. 2002. Evolutionary networks of maternal and paternal gene lineages in voles (Eothenomys) endemic to Japan. Journal of Mammalogy, 83: 852-865.

Iwasa MA, Suzuki H. 2003. Intra- and interspecific genetic complexity of two Eothenomys species in Honshu, Japan. Zoological Science, 20: 1305-1313.

森脇和郎. 1999. ネズミに学んだ遺伝学. 岩波書店. 東 京.

Saitoh M, Obara Y. 1988. Meiotic studies of interracial hybrids from the wild population of the large Japanese field-mouse, Apodemus-speciosus-speciosus. Zoological Science, 5: 815-822.

Sato JJ, Hosoda T, Wolsan M, Suzuki H. 2004. Molecular phylogeny of arctoids (Mammalia: Carnivora) with emphasis on phylogenetic and taxonomic positions of the ferret-badgers and skunks. Zoological Science, 31: $111-118$.

Shinohara A, Campbell KL, Suzuki H. 2003. Molecular phylogenetic relationships of moles, shrew-moles and desmans from the New and Old Worlds. Molecular Phylogenetics and Evolution, 27: 247-258. 
Shinohara A, Suzuki H, Tsuchiya K, Zhang Y-P, Luo J, Jiang X-L, Wang Y-X, Campbell KL. 2004. Evolution and biogeography of talpid moles from Continental East Asia and the Japanese Islands inferred from mitochondrial and nuclear gene sequences. Zoological Science, 21: 1177-1185.

鈴木仁. 2002. 日本産野生ネズミ類の起源と地理的変 異. 生物の科学 遺伝, 56(2): 57-61.

鈴木仁. 2003. 保全遺伝学. “第 10 章小型哺乳類” (小 池裕子. 松井正文). 159-174. 東京大学出版会. 東京.

Suzuki H, Sato JJ, Tsuchiya K, Luo J, Zhang Y-P, Wang YX, Jiang X-L. 2003. Molecular phylogeny of wood mice (Apodemus, Muridae) in East Asia. Biological Journal of the Linnean Society, 80: 469-481.

Suzuki H, Yasuda SP, Sakaizumi M, Wakana S, Motokawa M, Tsuchiya K. 2004. Differential geographic patterns of mitochondrial DNA variation in two sympatric species of Japanese wood mice, Apodemus speciosus and A. argenteus. Genes and Genetic Systems, 79: $165-176$.

Terashima M, Furusawa S, Hanzawa N, Tsuchiya K, Suyanto A, Moriwaki K, Yonekawa H, Suzuki H. 2005. Phylogeographic origin of Hokkaido house mice (Mus musculus) as indicated by maternal, paternal and biparental inheritance molecules. Heredity (in press)

Tsuchiya K, Suzuki H, Shinohara A, Harada M, Wakana S, Sakaizumi M, Han S-H, Kryukov AP. 2000. Molecular phylogeny of East Asian moles inferred from the sequence variation of the mitochondrial cytochrome $b$ gene. Genes and Genetic Systems, 75: 17-24.

Yamada F, Takaki M, Suzuki H. 2002. Molecular phylogeny of Japanese Leporidae, the Amami rabbit Pentalagus furnessi, the Japanese hare Lepus brachyurus, and the mountain hare Lepus timidus, inferred from mitochondrial DNA sequences". Genes and Genetic Systems, 77: 107-116. 